\title{
STRUCTURE AND FLOW IN THE MARGIN OF THE LAW DOME ICE CAP, ANTARCTICA \\ (Abstract)
}

by

Neal W. Young

(Antarctic Division, Department of Science, Channel Highway, Kingston, Tasmania 7150, Australia)

\begin{abstract}
The internal structure of the Law Dome ice cap is being investigated by studying ice cores obtained from several sites along the summit-Cape Folger line. Profiles of measured physical properties for four of the ice cores from near the margin of the ice cap are presented. A comparison of the profiles shows a gradual increase and then decrease in crystal size, and the development of strong crystal anisotropy in the upper half of the ice thickness. But in the lower part there is a complex multi-layer crystallographic structure, with an interleaving of ice which has markedly different physical properties. The development of the physical properties in the ice cores is discussed in terms of the deformation in the ice cap in the neighbourhood of the bore holes and the movement of the ice over the rough bedrock. The interdependence of the physical properties and the flow within the ice cap and their effect on other proxy records obtained from the ice cores are also explored.

The Law Dome is a small ice cap, about $200 \mathrm{~km}$ in diameter, adjoining the main Antarctic ice sheet. It is being
\end{abstract}

studied as a model ice cap, using surface surveys and ice-core drilling. It is large enough to have most of the features of larger ice sheets but small enough to be investigated in considerable detail. The four cores were drilled within $10 \mathrm{~km}$ of the coast at Cape Folger and lie approximately along a flow line. Each of the cores covers the Holocene and at least the later part of the Last Glacial Maximum. Two of the cores are within $40 \mathrm{~m}$ of bedrock and the remaining two, in thinner ice nearer the coast, are within a few metres of bedrock. Physical properties which were measured include: crystal size, texture and orientation; bubble size, orientation and distribution; and visible stratigraphy. The stratigraphy in the upper layers is related mainly to the occurrence of surface melting during the warmer months of the year. Additional supporting information is available from measurements of the physical properties on shallow cores up-stream of the four bore holes, from radio echo-sounding profiles and from other studies on the ice cores. This data is used in the discussion of the velocity field in the ice cap.

\section{$\mathrm{N}_{2} \mathrm{O}$ MEASUREMENTS ON AIR EXTRACTED FROM ANTARCTIC ICE CORES}

\author{
(Abstract) \\ by \\ D. Zardini* **, D. Raynaud*, D. Scharffe*** and W. Seiler** \\ * (Laboratoire de Glaciologie et Géophysique de l'Environnement, \\ B.P. 96, 38402 St Martin d'Hères Cédex, France) \\ ** (Institut für Atmosphärische Umweltforschung, Garmisch, Federal Republic of Germany) \\ *** (Max-Planck Institut, Mainz, Federal Republic of Germany)
}

\section{ABSTRACT}

A method has been developed for measuring $\mathrm{N}_{2} \mathrm{O}$ concentrations in the air extracted from the bubbles contained in ice cores. The air extraction is performed by cutting the ice into very small pieces with a rotating knife, in a controlled atmosphere. The $\mathrm{N}_{2} \mathrm{O}$ concentrations are measured by gas chromatography. The complete original procedure will be discussed, and the results of the different experimental tests given, with a discussion of the uncertainties.

This method has been used to perform about 40 measurements on Antarctic ice samples. Ten air samples from the D57 core date approximately from the beginning of the seventeenth and twentieth centuries. The others were taken from the Dome $\mathrm{C}$ core and date from the Holocene and the period around the Last Glacial Maximum. The D57 results are in agreement with those of Pearman and others (1986), leading to a similar pre-industrial $\mathrm{N}_{2} \mathrm{O}$ level (270-290 ppb volume). Furthermore, our Dome C results suggest that during the Last Glacial Maximum atmospheric $\mathrm{N}_{2} \mathrm{O}$ content was not drastically different from the recent period.

\section{REFERENCE}

Pearman G I, Etheridge D, Silva F de, Fraser P J 1986 Evidence of changing concentrations of atmospheric $\mathrm{CO}_{2}$, $\mathrm{N}_{2} \mathrm{O}$ and $\mathrm{CH}_{4}$ from air bubbles in Antarctic ice. Nature 320(6059): $248-250$ 